\title{
Problem Solving Skills on Direct Current Electricity through Inquiry- Based Learning with PhET Simulations
}

\author{
Lia Yuliati \\ Physics Department, Faculty of Mathematics and Natural Sciences, Universitas Negeri \\ Malang (State University of Malang), Indonesia, lia.yuliati.fmipa@um.ac.id

\section{Cycin Riantoni} \\ Science Education Department, Faculty of Education, Jambi University, Indonesia

\section{Nandang Mufti} \\ Physics Department, Faculty of Mathematics and Natural Sciences, Universitas Negeri \\ Malang (State University of Malang), Indonesia
}

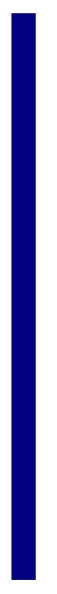

\begin{abstract}
The purpose of this research was to explore students' problem-solving skills through inquiry-based learning with PhET simulation, focussed on direct current electricity matter. The research used a mixed method approach with an embedded experimental model with 34 prospective physics teacher at the State University of Jambi, Indonesia. The data was obtained by using open-ended questions. Data were collected using tests and interviews regarding inquiry-based learning with PhET simulations. Data analysis was done by using Kruskal Wallis test and rubric for physics problem-solving skills. Problem-solving skills were classified into the scientific approach, plug and chug (structured manner and unstructured manner), memory-based approach, and no clear approach. The research showed that there are many students with solving problems using unstructured methods, memorybased approach and no clear approach, which then influences students' problemsolving skills. The students who applied a scientific approach had better problemsolving skills than students using the other approaches. Thus, student problemsolving skills are influenced by the type of approach used in solving the problem.
\end{abstract}

Keywords: problem-solving skills, direct current electricity, inquiry-based learning, PhET simulations

\section{INTRODUCTION}

Problem-solving is one of the key factors of science education (Ceberiol et al., 2016; Ibrahim \& Rebello, 2012), including physics education (Adams \& Wieman, 2015; Docktor \& Mestre, 2014; Docktor et al., 2010). Problem-solving is one of the aspects of physics learning goals in university, based on the mastery of physics concepts (Sutopo,

Citation: Yuliati, L., Riantoni, C. \& Mufti, N. (2018). Problem Solving Skills on Direct Current Electricity through Inquiry-Based Learning with PhET Simulations. International Journal of Instruction, 11(4), 123-138. https://doi.org/10.12973/iji.2018.1149a 
2016). In addition, problem-solving is also used by physics instructors as a mechanism for physics learning and judging if the concept has been studied (Docktor et al., 2016; Caberiol et a.1, 2016).

Over the last few decades, some research into problem-solving in physics education has been conducted. Generally, the research can be categorized into five main topics, namely; identifying the difference between expert and novice, an example of a problemsolving item, representation used in problem-solving, using mathematics in physics, and evaluation of learning strategy for problem-solving (Docktor \& Mestre, 2014). Among those five topics, the research of expert and novice is the one most commonly studied. Most of the researchers categorize expert and novice in problem-solving (Docktor et al., 2016; Docktor \& Mestre, 2014), the difference of problem-solving approach of expert and novice (Docktor \& Mestre, 2014; Walsh et al., 2007) and metacognition in problem-solving (Docktor \& Mestre, 2014).

A problem-solving approach is one of the most significant topics of problem-solving research. A problem-solving approach is related to various ways used by the students to solve the problems connected to experience, perception, and understanding of a certain phenomenon (Walsh et al., 2007). A problem-solving approach is linked with the mathematical process, concept application, physical and verbal link, and graph and diagrammatic representations used by the students in problem-solving (Kohl \& Finkeilstein, 2005)

While research on problem-solving has been much conducted, the concept of direct current electricity connected to the problem-solving skills has been rarely conducted. Some researchers of physics education usually assess problem-solving skills focusing on characteristics and reasoning (Docktor et al., 2016), and the ability to connect various representations linked with physics concepts (Ceberiol et al., 2016) without considering the approach type used by the student.

In the topic on direct current electricity, concepts such as Ohm Law, current, and voltage within the series and parallel circuits, Kirchoff Law about current and voltage as well as the Law of Energy and charge conservation are prerequisite concepts that should be understood in problem-solving (Riantoni et al., 2017). Some researchers report that students have misconceptions regarding these prerequisites, for example, students have difficulty in describing and interpreting a circuit diagram (Engelhardt \& Beichner, 2004; Kock et al., 2014; Stetetzer et al., 2013) and they are confused about the concept of current, potential difference, and resistor (Engelhardt \& Beichner, 2004; Smith \& Kampent, 2011; Kock et al., 2014). Some students considered current and resistor as the main concept, while the voltage was considered as the consequence of the current and that it does not become the resistor (Kock et al., 2014; Engelhardt \& Beichner, 2004).

Inquiry-based learning can be implemented to overcome the issue of misconceptions. Inquiry-based learning provides students with direct experience (Hardianti \& Kuswanto, 2017) and involves them as active participants in solving problems (Zuckerman et al., 2009; Lotter et al., 2009) so that the learning process helps the student to solve the problem (Walsh et al., 2007). The use of inquiry in learning can 
develop a student's understanding of not only the product but also the process (Wenning, 2011). A good learning process can provide emotional support for the student and can be a funny way to teach (Irajzad et al., 2017).

The use of media in inquiry-based learning can help facilitate the learning process. That media can be a PhET simulation. The integration of PhET simulation and inquiry-based learning can build a conceptual understanding of physics through exploration (Perkins et al., 2006) and be used to analyze the results of a problem-solving activity (Caberiol et al., 2016). This article aims to describe the use of an approach used by prospective physics teachers in solving problems, especially those linked to the direct current electricity topic, by using inquiry-based learning with PhET simulations, and its influence on problem-solving skills.

\section{REVIEW OF LITERATURE}

\section{Problem Solving Skills}

Problem-solving is a complex cognitive process and research in this field is related to cognitive psychology (Docktor \& Mestre, 2014). Problem-solving in physics education is often represented in the form of abstract symbols that ignore the physical meaning of a concept. In fact, if we want students to learn and understand how to use symbolic representations that are part of the process (eg, the mathematical description of the process) then we must relate abstract concepts with more concrete descriptions (Rosengrant, et al., 2009).

Some physics education researchers have investigated student problem-solving skills by observing how their expert and novice behaviors solve physics problems. Some findings indicate that the expert problem-solving type begins by describing problem information qualitatively and using information to find a solution strategy before providing an answer (Walsh, et al., 2007; Ogilvie, 2009; Hull, et al., 2013; Docktor \& Mestre, 2014; Docktor, et al., 2016). Students who are novice types begin to provide answers that are matched by the statement of problems and mathematical skills (Walsh, et al., 2007; Rosengrant, et al., 2009; Hull, et al., 2013; Docktor, et al., 2016). Expert-type students apply principles or concepts in problem solving in an organized manner (Rosengrant, et al., 2009; Ogilve, 2009; 2011; Hull, et al., 2013; Docktor, et al., 2016), whereas novicetype students focus on quantitative values in problems, such as variables in known problems (Rosengrant, et al., 2009). Expert type students organize their knowledge in a highly structured manner while novice type student's strategies are not based on knowledge structures, their understanding consists of random facts and has little conceptual meaning (Walsh, et al., 2007; Hull, et al., 2013). Expert type students have a way to simplify problem-solving, while novice-type students are slower in finding alternatives if they have difficulty (Hull, et al., 2013). Expert type students have a strong conceptual understanding, while novice-type students have low conceptual understanding, math skills, and the ability to apply knowledge and this becomes an obstacle in problem-solving (Hull, et al., 2013). 
According to Docktor et al. (2015), problem-solving skills consist of two levels, namely, explicit problem solving and traditional problem-solving. Meanwhile, Walsh et al. (2007) state that problem-solving skills can be classified into five levels; a scientific approach, a structured manner plug-and-chug, an unstructured manner plug-and-chug, a memory-based approach and no clear approach. The problem-solving skills levels mentioned by Docktor et al. (2015) and Walsh et al. (2007) have a similar goal in that they assess the problem-solving process based on conceptual steps.

\section{Inquiry-Based Learning with PhET Simulations}

Inquiry-based learning has many definitions. Inquiry-based learning views students as active thinkers who build their own understanding of interactions with phenomena, the environment, and other individuals (Pizzolato, et al., 2014). Inquiry-based learning begins by asking questions, finding answers, understanding and studying thoroughly like a scientist (Bilgin, 2009).

PhET Simulations is a project at the University of Colorado that develops a simulation tool focused on physics learning (Finkelstein, et al., 2005; Perkins, et al., 2006; Wieman, et al., 2010). This simulation is an accurate visual simulation model and represents dynamically from the principles of physics (Finkelstein, et al., 2005). PhET simulation uses a research-based approach that incorporates previous findings and selftesting to create simulations that support student engagement and understanding of physics concepts (Perkins, et al., 2006).

The PhEt simulation is a The Virtual Physics Lab. The Virtual Physics Lab is a nextgeneration computerized resource that seeks to incorporate research-based activelearning characteristics. The labs were developed to provide a variety of problemsolving activities that can be completed during class time. Students can work alone or in small groups to complete the labs and they receive rapid feedback from the computer simulation (Darrah, et al., 2014). The virtual labs have the advantage of being easier to use and in some cases safer than physical laboratories, and they are easily accessible at all times (Zacharia \& Jong, 2014; Caberiol, et al., 2016).

PhET simulations use dynamic graphs to animate the visual and conceptual models used by physicists. In many cases, the simulations show what the eye does not normally see, such as atoms, electrons, photons, and electric fields (Finkelstein, et al., 2005; Perkin, et al., 2006; Wieman, et al., 2010). All of PhET simulations directly complement the students' actions with animation (Perkin, et al., 2006). The advantages of PhET simulations are that they give students the opportunity to interact with dynamic visuals, focus on exploring inquiry, providing fast feedback and experience using multiple representations (Moore, 2013).

Learning in real and virtual labs (PhET interactive simulations) has advantages and disadvantages for students, so when learning in a real laboratory is combined with PhET interactive simulations on guided inquiry, learning the advantages and disadvantages of both can complement each other. Learning with PhET simulations has the benefit of being able to make the invisible appear and provide multiple representations (macroscopic, microscopic, graphics, etc.) of abstract concepts (Caberiol, et al., 2016) that can be applied in the problem-solving process. 


\section{METHOD}

\section{Research Design}

This research used a mixed method approach with an embedded experimental model Mixed methods research is a design for collecting, analyzing, and mixing both quantitative and qualitative research (or data) in a single study or series of studies to understand a research problem (Cresswell \& Clark, 2007). The research design used in this research is shown in Figure 1.

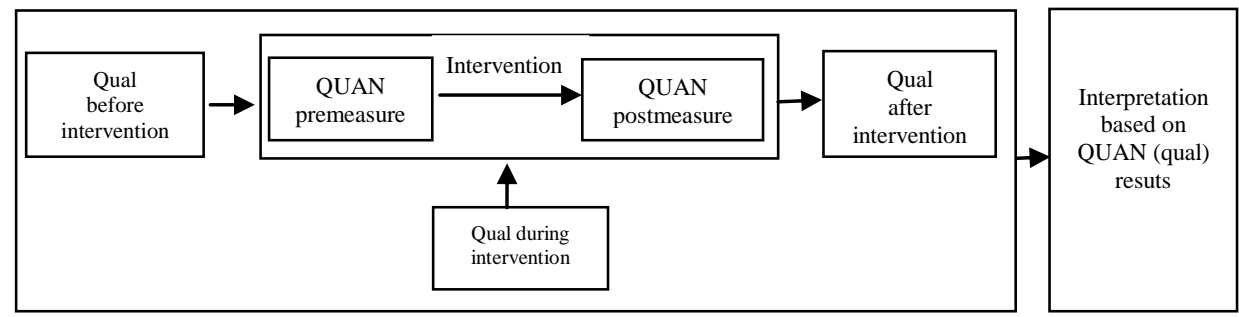

Figure 1

Embedded Experimental Model (Cresswell \& Clark, 2007)

\section{Participants}

Participants in the research were first-year Physics Education Department students at the State University of Jambi, Indonesia. Sampling was done by purposive sampling technique. Participants included both males $(n=4)$ and females $(n=30)$. All students used inquiry-based learning with PhET simulations.

\section{Research Instruments}

Research data was collected by test and interview. The test instrument used was a multiple-choice questionnaire of DIRECT (determining and interpreting resistive electric circuit concept) (Engelhardt \& Beichner, 2004). Interviews using an unstructured technique were conducted on all students to confirm their answers and to explore their problem-solving skills on direct-current electrical problems. To determine the validity and reliability of the questions, the test items were checked empirically. The empirical test results are shown in Table 1.

Table 1

The empirical test results of multiple-choice question

\begin{tabular}{lcl}
\hline & Result & \multicolumn{1}{c}{ Statistics } \\
\hline $\mathrm{N}$ & 103 & \\
Validity & 0.65 & Biserial Correlation KR-20 \\
Reliability & 0.78 & Cronbach's Alpha \\
\hline
\end{tabular}

\section{Procedure}

The research began with a pre-test and interview to determine the initial problemsolving skills of students in solving material direct current electricity. In addition, interviews were conducted to confirm student answers. The second stage was the 
implementation of inquiry-based learning with PhET simulations. The syntax of inquirybased learning consists of orienting and asking questions, hypothesis generation, planning, investigations, analysis and interpretation, model exploration and creation, conclusion and evaluation, communication and prediction (Bell, et al 2010). While the PhET simulation is applied in the exploration and creation stage in order to explore, test, revise and strengthen the results of the investigation. The third stage was post-test and interview.

\section{Data Analysis}

Data were analyzed quantitatively and qualitatively to find the characteristics of students' problem-solving skills and their changes after inquiry-based learning with PhET simulations, as well as the effect of inquiry-based learning with PhET Simulation toward problem-solving skills. Qualitative data analysis was done by the reduction of the test result and an interview. Data reduction results were then classified according to the problem-solving skills criteria as shown in Table 2.

Table 2

Assessment criteria for problem-solving skills

\begin{tabular}{|c|c|}
\hline Criteria & Characteristics \\
\hline $\begin{array}{l}\text { Scientific } \\
\text { approach }\end{array}$ & $\begin{array}{l}\text { - Analyzing the physical situation qualitatively and referring to the } \\
\text { involved physics concept } \\
\text { - Planning and finding out the solution systematically based on the } \\
\text { analysis } \\
\text { - Referring to the concept of finding out the solution process } \\
\text { - Evaluating the solution of problem }\end{array}$ \\
\hline \multicolumn{2}{|l|}{ Plug and chug: } \\
\hline $\begin{array}{l}\text { Structured } \\
\text { manner }\end{array}$ & $\begin{array}{l}\text { - The qualitative analysis of situation is based on the needed formulation } \\
\text { - The solution planning is based on the variable and systematical } \\
\text { procedure } \\
\text { - Referring to the concept of getting the process of getting the solution } \\
\text { - Evaluating the solution of problem }\end{array}$ \\
\hline $\begin{array}{l}\text { b. Unstructured } \\
\text { manner }\end{array}$ & $\begin{array}{l}\text { - The situation analysis was based on the involved variable } \\
\text { - Starting the process by choosing the formulation based on the variable } \\
\text { in the trial and error system } \\
\text { - Referring to the concept of the variable } \\
\text { - Not evaluating the solution of problem }\end{array}$ \\
\hline $\begin{array}{l}\text { Memory-based } \\
\text { approach }\end{array}$ & $\begin{array}{l}\text { - Analyzing the problem based on the situation found in the past time } \\
\text { - The process is started by suiting the given variable with the example } \\
\text { that has been given } \\
\text { - Referring to the concept of the variable } \\
\text { - Not evaluating the solution }\end{array}$ \\
\hline $\begin{array}{ll}\text { No } & \text { clear } \\
\text { approach }\end{array}$ & $\begin{array}{l}\text { - Analysis of situation based on the given variable } \\
\text { - The procedure is started by using the variable randomly } \\
\text { - Applying the variable as a term } \\
\text { - Not evaluating the solution of problem }\end{array}$ \\
\hline
\end{tabular}


The analysis was done by the prerequisite test of normality and homogeneity and a further test. A normality test is done by using the Kolmogorov Smirnov test. Data is normally distributed if the value of significance obtained is greater than the level of significance $(\mathrm{p}>0.05)$. The homogeneity test was conducted using the Levene test. Homogeneous variances when the value of significance obtained is greater than the level of significance $(\mathrm{p}>0.05)$. Further test statistic used in this research was Kruskal Wallis Test.

\section{FINDINGS AND DISCUSSION}

\section{Description of Approach Type Used by the Students in Problem-Solving}

Grouping the approach type used by the students in solving the problem of direct current electricity was done to identify the tendency of the approach type applied by the students after they were taught by using inquiry-based learning with PhET simulations. The results showed that before the students were taught using inquiry-based learning with $\mathrm{PhET}$ simulations, their problem-solving approach was $14.28 \%$ of the students applied an unstructured manner and $85.7 \%$ of those who used no clear approach. After the intervention, the approach type used by the students changed. Figure 2 shows the change in problem-solving approach type applied by the students who had been taught using inquiry-based learning with PhET simulations.

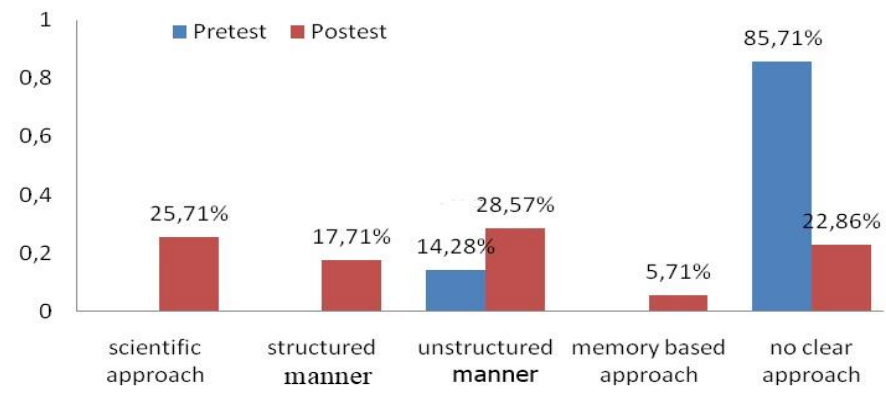

Figure 2

Type of students' problem-solving approach

\section{Example of Scientific Approach Application}

The scientific approach is one of the problem solving approaches that use concepts in problem-solving process. The students who applied the scientific approach always started the problem-solving process by analyzing the problems qualitatively. They planned the solution systematically, applied the concept and evaluated the problemsolving result (Walsh et al., 2007).

Based on the data, $25.71 \%$ of the students, or nine students from 34 students, applied the scientific approach in problem-solving after they were taught using inquiry-based learning with PhET simulations. These results show the change in student's problemsolving patterns when solving the problem of direct current electricity compared to their previous methods that tended to use no clear approach and an unstructured manner. 
The use of a scientific approach by the students was also supported by the interview data as follows.

Lecturer: "When you answered the problem related to potential difference concept in this circuit, the conclusion was there was the decrease in potential difference when the switch was closed. Please explain again the process of getting such conclusion"

Student : "If the switch was opened, the current of the intersection 2 did not flow, so the circuit was series. If it was a series circuit, so the amount of current at each point was the same."

$L \quad$ : "ok"

S1 : "the question in the item is the change of voltage."

L : "ok"

S1 : "If the switch was closed, so the circuit becomes the combination of parallel and series. In a parallel circuit, there will be a current share so that it will reduce.

L : "what is that?

S1 : "Voltage".

L : "And then"

S1 : ' 'the explanation is like this' (showing the process on the answer sheet)

The student's answer in the interview shows the beginning problem-solving process. Students try to explain the answer by analyzing the problem in detail first. Students then elaborate the answer systematically. This shows that there is a suitability of student problem-solving process with scientific approach characteristics.

\section{The Example of the Application of Structured Manner Plug-And-Chug Approach}

The students who applied the structured manner approach in problem-solving always started the process by analyzing the problem based on the formulation. They planned the solution based on the variable of the problem, explained the answer systematically, applying the concept in problem-solving, and evaluated the answer (Walsh et al., 2007). Based on Figure 2, 17.14\% of the students, or six people from 34 students, used a structured manner model in problem-solving after they were taught using inquiry-based learning with PhET simulations. This result shows that there was an increase in student numbers applying a structured manner compared to before they were taught using inquiry-based learning with PhET simulations.

The process of student's problem-solving using structured manner approach was supported by the interview results.

$L \quad:$ "When you look at the picture in the item, how is the change of potential difference if the switch of the circuit is opened and closed?"

S2 : "When I found out by using formulation when the switch was opened, the current did not flow in the second resistor. This case caused the circuit became series circuit between the resistor 3 and resistor 1."

$L \quad:$ : $O k "$

S2 : "If we find out the potential difference, it will be 6 volts."

$L \quad$ : "Which potential difference having 6 volts?"

$S 2 \quad$ : "The potential difference between $R_{3}$ and $R_{l}$. When the switch was closed, the circuit will be the combination of series and parallel, so that we find out the parallel one first."

$L \quad$ : "Which parallel circuit that you mean?"

S2 : "Between R1 and R2" 
$L \quad:$ :And then?"

S2 : "After that, the result is series with R3. So the potential difference is 3,99 volts. So, the conclusion is it decreases.

The interview results show that the students analyzed the circuit based on the formulation at the beginning of the problem-solving process. This case is supported by the student who stated that "When I find out by using formulation when the switch was opened, the current did not flow in the second resistor. This case caused the circuit became series between the resistance 3 and resistance." The test and interview showed the suitability of student's explanation and the characteristics of a structured manner approach.

\section{Example of the Application of Unstructured Manner Plug-and-Chug Approach}

The students who solved the problems by using an unstructured manner always started the problem-solving process by analyzing the problems based on the variable of the problem. After that, the students determined the equation that would be used based on the variables that had been written by using trial and error and they tended to not to evaluate the answer (Walsh et al., 2007). Based on Figure 2, 28.57\% of students applied an unstructured manner in solving the problem of direct current electricity after they were taught by using a combination of guided inquiry with PhET simulations. In this research, a structured way is the most used approach by students in problem-solving compared to other approaches.

The student's problem-solving process is aligned with the criteria of an unstructured manner approach. This case is strengthened by the following interview results.

$L \quad$ :"You got the power change was 2.4 watts, please explain again the process of getting such answer!"

S3 : (the student was reading the item)

S3 : "To solve this problem, I used the Power formulation. Since there are many power formulations, so I wrote the formulations in the order I do not forget. After that, I determined the formulation that could be applied based on the variable known."

$S 3$ : "After that, I entered the voltage of $6 \mathrm{~V}$, the resistor was $10 \mathrm{Ohm}$, the similar thing I did to the picture 2, but the resistor was 10. The resistor 10 was added to the resistor 20 becoming 30. The voltage was 6 quadratic."

$L \quad:$ "The value of 1.2 watts, is it in the resistor A or in the power of the circuit?"

S3 : "Power in picture 2 after it was added with 20 Ohm"

$L \quad:$ :Read again please the problem of the item?"

S3 : "After that, it was obtained 3.6 and this is 1.2. So, the power change was the result of reducing the power of the circuit 1 and 2. Why was it reduced? Because in circuit 2, it was added with $20 \mathrm{Ohm}$. And then, in circuit 1, it was obtained 3.6 watts and in circuit 2 it was obtained 1.2 watts so that the power decreased."

$L \quad:$ "The problem being questioned was the power of resistor or circuit?"

S3 : "In resistor A"

$L \quad$ : "It should be in resistor A, but what did you find out?"

S3 : "All of them"

$L \quad:$ "You should find out the resistor A of the circuit 2 minus circuit 1."

S3 : "Yes, I was wrong in the last finishing." 
The interview result shows that when solving the problem, the student identifies the equation first and then solves the problem by using the equation. Additionally, the student did not evaluate the results of the problem-solving process resulting in a wrong answer. The results of test and interview showed the problem-solving process used by students was aligned with the criteria of an unstructured manner approach.

\section{Example of Memory-Based Approach Application}

The students who applied the memory-based approach to solving the problems always started the problem-solving process by matching the variable with a problem they had solved before (Walsh et al., 2007). In addition, the students who applied a memorybased approach did not use the concept in problem-solving as well. Figure 3 shows a student answer using a memory-based approach to solve a problem.

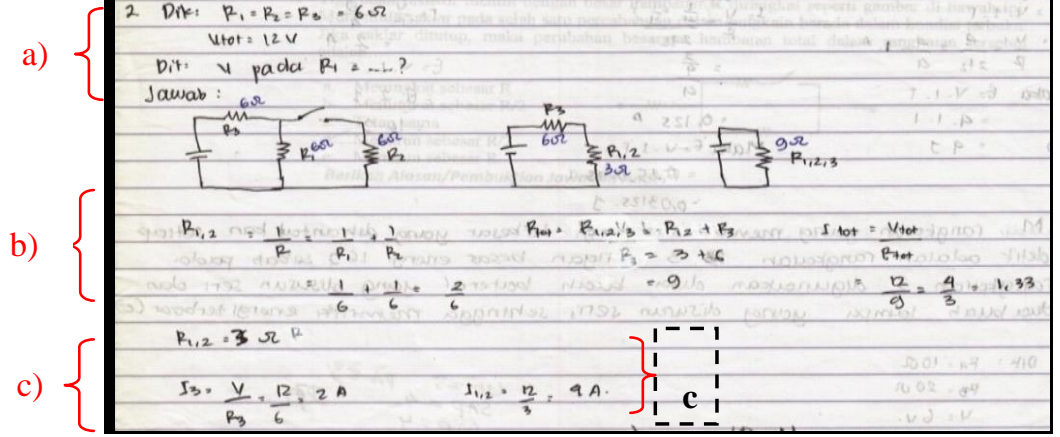

Figure 3

Student answers using a memory-based approach to the concept of potential differences in series and parallel circuits

a) analyze known variables and problem questions
b) not focus on the problem and not use the relevant concept
c) not evaluate the answer of problem

The method of problem-solving used by the student above was similar to the student who used an unstructured manner approach, but if we examine the interview results, we find that the student's approach was more aligned with the criteria of a memory-based approach. The results of interview transcript are presented as follows:

$L \quad$ : "Explain again please the process of getting the answer related to potential difference concept in the series and parallel circuits."

S4 : "I was unfinished in explaining"

$L \quad:$ "Which one that made you were confused? Explain please."

S4 : (reading the item)

S4 : "I did this item together with five cases yesterday. The question of the item is the change of potential difference around $R_{l}$. I had tried to find the I, but to find out the potential difference, I don't understand."

Interview results show that the approach used by the student is a memory-based approach. This was observed when the student was asked to explain how to get the answer. The student stated that the process of coming to a solution was based on 
exercises he had done before. All test and interview criteria indicate that the type of approach used by this student is a memory-based approach.

\section{Example of No Clear Approach Application}

The students who applied no clear approach to solve the problems usually did not apply the concept in prpblem solving process. They usually did the solving process randomly, did not focus on the problem, got difficulty in the explaining the process and tended to focus on the variables given in the item and used the terms in the solving process (Walsh et al., 2007).

Based on the results of the test and interview, $22.85 \%$ of the students, or eight people of 35 students, applied no clear approach in the process of solving the problem of direct current electricity after they were taught by using guided inquiry learning helped by PhET. The use of a variable as a term was also supported by the interview data as follows.

$L$ : "When you finished the problem of potential difference in a certain circuit like in the picture, did the answer increase or decrease?"

S5 : (re-reading the item), "decreased"

$L$ "How could you think that?"

S5 : "First, the switch was opened."

$L$ : "The circuit?"

S5 : "The series circuit, since the picture becomes like this (showing the picture). The current was similar in the series circuit, so when the switch was closed, there would be division since the circuit had a parallel part."

$L$ : "What was divided?"

S5 : "The current. So, if this is the voltage, so it will be divided again.

S5 : (getting confused). "The current was divided by two again, for example here is six and here is six. So, this six is divided into two for the voltage. Therefore, it decreased."

Test results and interviews showed that the students solved the problem based on the criteria of no clear approach. This is observed when students explain the process of getting answers randomly without any mathematical process and using only those terms. In addition, students are confused and have no mastery of concepts, such as currents and stresses, in finding the answers.

Classifying the type of approach in problem-solving aims to understand students' thinking skills about direct current electric problems. Before they were taught using inquiry-based learning with $\mathrm{PhET}$ simulations, students tended to apply unstructured ways and there was no clear approach in the problem-solving process. This happened because students did not understand the concept of direct electrical current that must be applied in the problem-solving process. This result is in accordance with Docktor \& Mestre's (2014) statement that the strategy in problem-solving is usually based on applying the relevant concepts or principles of physics and planning concept applications under special conditions. The results of other studies on trends in approaches used in solving problems on energy and electric power topics also indicate that the problem-solving approach widely used by students is not a clear approach (Riantoni et al., 2017). 
After inquiry-based learning with PhET simulations were introduced, some changes occurred to the problem-solving strategies used by some students to become more scientific, structured, and memory-based. Inquiry-based learning with PhET simulations influenced the change of approach used by the students in problem-solving. The changes of the approach used might be caused by the effect of students' learning experience since this case was relevant to the explanation of Ibrahim \& Rebello (2012) stating that the effect of understanding and experience with the topic learned can stimulate the approach change used in problem-solving. One of the most effective influences was the use of PhET since the use of PhET as the virtual laboratory can support in developing and changing the conceptual; and help the students to understand the physical phenomena in any scopes of physics learning (Martinez et al., 2011) which is beneficial in the problem-solving process.

Inquiry-based learning has invited students to investigate and analyze the experimental results and to train students to solve the problem based on the data. This learning helps students develop problem-solving skills of physics in daily life so that the results of this study showed an increase in the problem-solving skills. Although there is a better chance of improving the problem-solving approach, the findings of this research showed that there were few students who could apply a scientific approach. This occurred because many students did not analyze problems qualitatively in the problem-solving process, such as simplifying the circuit diagram and describing the problems; an important aspect in starting the problem-solving process. The results of this research supported Meltzer's (2005) research which stated that qualitative analysis of the problem is a key factor in problem-solving and students often have difficulty to do such a thing. The qualitative analysis of making a diagram is included in problem-solving solutions to understand better the problem and the visualization of the problem (Ibrahim \& Rebello, 2012). Only the few students used a scientific approach in the process of problem-solving of direct current electric because students did not understand the concept since one of the factors influencing the approach used by the students in problem-solving is their conceptual understanding and experience (Ibrahim \& Rebello, 2012). The results of this research were supported by Riantoni, et al. (2017) research showing that only one student out of 44 could apply the scientific approach to the problem-solving process.

Another interesting finding in this research was on students using structured manner plug-and-chug approaches. The structured manner plug-and-chug approach was used by students who usually use a scientific approach to solve the problem of direct current electricity. It is used by students when they solve problems with difficulty level problems that are not too high (Walsh et al., 2007). That means that the students used a scientific approach when they finished the problem with the higher difficulty level and needed analysis as well as formulation manipulation. In addition, those students who were successful in mathematics also tended to use plug and chug in the problem-solving process (Kohl \& Finkelistein, 2005). Other research results also show that students do not use the same approach to solve problems involving similar physics principles. If the problem is different, then most students use logic rather than using the principles of physics to answer the problem of conceptual physics (Mason \& Singh, 2016). 
The result of Kruskal Wallis test showed that scores of chi-square is 17:23 with a significance of $0.002 \quad(<0.05)$. These results indicate that there are significant differences in student problem-solving skills based on the type of approach used. That is, the type of approach that students use has a significant effect on problem-solving skills. There is a difference between the unstructured manner plug-and-chug approach, memory-based approach and no clear approach. Students using the unstructured manner plug-and-chug approach, memory-based approach and no clear approach do not always reflect good concept mastery. Most students understand the concept of direct current electricity and others have difficulty in applying concepts in the problem-solving process. This problem happened because the students might still hold tightly the way of thinking about the three approaches. This case was in line with the statement of Sabella $\&$ Redish (2007) who mentioned that a bad problem-solving process was possible when students held tightly to certain knowledge structures as a response of certain problems so that if the knowledge structure activated did not have the information needed for such a problem, the students could not access the knowledge needed to solve it. The findings of the research indicate that students who used the unstructured manner approach, plug and chug approach, memory-based approach and no clear approach in the problemsolving process did not always understand the concept but the difficulty arose in applying the concept in the problem-solving process. This problem occurs probably because students still have a mindset of the three approaches before. This case supports Sabella \& Redish (2007) who states that difficulties in solving problems can occur because students still use certain knowledge structures so that the knowledge-enabled structure does not provide the information needed for the problem Students cannot remember the knowledge needed to solve the problem even though they had that knowledge before.

This research showed that the type of problem-solving approach used by the students can influence problem-solving skills. A scientific approach is the best approach that can be used to be successful in problem-solving. The skills needed to solve the problem are complex and require an organized conceptual understanding, relevant procedural knowledge and a metacognition strategy to enable someone to formulate a strategy, implement it, and evaluate the solution from many perspectives (Ogilvie, 2009).

\section{CONCLUSION}

There are five types of approaches in problem-solving, such as the scientific approach, plug and chug, the memory-based approach and no clear approach, as feasible ways to find solutions on direct electrical problems. The results of this research showed that a few students solve problems by using a scientific and structured approach. Students tend to use unstructured, memory-based approaches, and no clear approach. The results of this research conclude that students should be trained to solve problems by using various types of approaches in active learning, such as inquiry-based learning with PhET simulations. The learning uses a scientific approach designed to improve students' problem-solving skills. The results of this research recommend to the future researchers to explore aspects of conceptual mastery and conceptual change with appropriate learning strategies to develop problem-solving skills. 


\section{REFERENCES}

Adams, W.K. \& Wieman, C.E. (2015). Analyzing the many skills involved in solving complex physics problems. American Journal of Physics, 83/5, 459-467.

Bell, T.; Urhahne, D.; Schanze, S. \& Plouzhner, R. (2010). Collaborative Inquiry Learning: Models, Tools, and Challenges. International Journal of Science Education, 32/3, 349-377.

Bilgin, I, (2009). The effects of guided inquiry instruction incorporating a cooperative learning approach on university students' achievement of acid and bases concepts and attitude toward guided inquiry instruction. Scientific Research and Essay, 4/10, pp. 1038-1046.

Ceberiol, M.; Almudi, J.S. \& Franco, A. (2016). Design and application of interactive simulations in problem solving in university-level physics education. Journal Science Education and Technology, 25/4, 590-609.

Creswell, J.W. \& Clark, V.P. (2007). Designing and conducting mix methods research. Thousand Oaks, CA: SAGE.

Darrah, M., Humbert, R., Finstein, J., Simon, M., Hopkins, J. (2014). Are Virtual Labs as Effective as Hands-on Labs for Undergraduate Physics? A Comparative Study at Two Major Universities. Journal of Science Education and Technology. 23/3, 803-814

Docktor, J.L.; Strand, N.E.; Mestre, J.P. \& Ross, B.H. (2010). A conceptual approach to physics problem solving. American Institute of Physics, 1289/1, 137-140.

Docktor, J.L. \& Mestre, J.P. (2014). Synthesis of discipline-based education research in physics. Physical Review Special Topics-Physics Education Research, 10/2, 020119102011958.

Docktor, J.L.; Strand, N.E.; Mestre, J.P. \& Ross, B.H. (2015). Conceptual problem solving in high school physics. Physical Review Special Topics-Physics Education Research, 11/2, 0201061-02010613.

Docktor, J.L.; Dornfeld, J.; Frodermann, E.; Heller, K.; Hsu, L.; Jackson, K.A.; Mason, A.; Qing X. Ryan. \& Yang, J. (2016). Assessing student written problem solutions: a problem-solving rubric with application to introductory physics. Physical Review Physics Education Research, 12/1, 0101301-01013018.

Engelhardt, P.V. \& Beichner, J.R. (2004). Students' understanding of direct current resistive electrical circuits. American Journal of Physics, 72/1, 98-115.

Finkelstein, N.D., Adam, W. K., Keller, C. J., Kohl, P. B., Perkins, K. K., Podolefsky, N. S., Reid, S, (2005). When Learning About The Real World Is Better Done Virtually: A Study Of Substituting Computer Simulations For Laboratory Equipment. Physics Review Special Topics-Physics Education Research, Vol 1, No. 010103. 
Hardianti, T. \& Kuswanto, H. (2017). Difference among Level of Inquiry: Process Skill Improvement at Senior High School in Indonesia. International Journal of Instruction, 10/2, 119-130.

Hull, M.M ., Kuo, E., Gupta, A \& Elby, A, (2013). Problem-Solving Rubrics Revisited: Attending To The Blending Of Informal Conceptual And Formal Mathematical Reasoning, Physics Review Special Topics-Physics Education Research, Vol. 9, No. 010105 .

Ibrahim, B. \& Rebello, N.S. (2012). Representational task format and problem solving strategies in kinematics and work. Physics Review Special Topics-Physics Education Research, 8/1, 0101261-01012619.

Irajzad, F.; Pishghadam, R. \& Shahriari, H. (2017). Examining the Stroking Behavior of English, Persian, and Arabic School Teachers in Iran: A Mixed-methods Study. International Journal of Instruction, 10/1, 219-236.

Kock, Z.; Taconis, R.; Bolhuis, S. \& Graveimejer, K. (2014). Creating A Culture Of Inquiry In The Classroom While Fostering An Understanding Of Theoretical Concepts In Direct Current Electric Circuits: A Balanced Approach. International Journal of Science and Mathematics Education, 13, 45-69.

Kohl, P.B. \& Finkeilstein, N.D. (2005). Student representational competence and selfassessment when solving physics problems. Physics Review Special Topics-Physics Education Research, 1/1, 0101041-01010411.

Martinez, G., Naranjo, F. L., Perez, A. L \& Suero, M. I,. (2011). Comparative Study Of The Effectiveness Of Three Learning Environments: Hyper-Realistic Virtual Simulations, Traditional Schematic Simulations, and Traditional Laboratory. Physics Review Special Topics-Physics Education Research, Vol 7, No. 020111.

Mason, A.J. \& Singh, C. (2016). Surveying college introductory physics student attitudes and approaches to problem solving. European Journal of Physics, 37/5, 1-23.

Meltzer, D. (2005). Relation between student problem solving performance and representation format. American Journal of Physics. 73/5, 463-478.

Moore, E.B., Herzog, T. A \& Perkins, K. K, (2013). Interactive Simulations As Implicit Support For Guided-Inquiry. Chem. Educ. Res. Pract, Vol. 14, 257-268.

Ogilvie, C.A. (2009). Changes in Students Problem Solving strategies in a Course That Includes Context - Rich, Multifaceted Problems. Physics Review Special TopicsPhysics Education Research, 5/2, 0201021-0201021.

Perkins, K.; Adam, W.; Dubson, M.; Finkeilstein, N.; Reid, S.; Wieman, C. \& Lemaster, R. (2006). Phet: interactive simulations for teaching and learning physics. The Physics Teacher, 44, 18-23.

Pizzolato, N., Fazio, C., Mineo, R. M. S., and Dominique Persano Adorno, D. P. (2014). Open-inquiry driven overcoming of epistemological difficulties in engineering 
undergraduates: A case study in the context of thermal science. Physics Review Special Topics-Physics Education Research. 10. 010107.

Riantoni, C. Yuliati, L. Mufti, N. \& Nehru. (2017). Problem-solving approach in electrical energy and power on students as physics teacher candidates. Indonesian Journal of Science Education, 6/1, 55-62.

Rosengrant, D., Heuvelen, A and Etkina, E,. (2009). Do Students Use And Understand Free-Body Diagrams?. Physics Review Special Topics-Physics Education Research, 5, 010108.

Sabella, M \& Redish, E. (2007). Knowledge organization and activation in physics problem solving. American Journal of Physics, 75/11, 1017-1029.

Smith, D.V. \& Kampen, P.V. (2011). Teaching electric circuits with multiple batteries: a qualitative approach. Physics Review Special Topics-Physics Education Research, 7/2, 0101101-01011010.

Stetetzer, M.R.; Kampen, P.V.; Shaffer, P. S. \& McDermott, L. C. (2013). New insights into student understanding of complete circuits and the conservation of current. American Journal of Physics, 81/2, 134-143.

Sutopo. (2016). Pemahaman mahasiswa tentang konsep-konsep dasar gelombang mekanik. Jurnal Pendidikan Fisika Indonesia, 12/1, 41-53.

Walsh, L.; Howard, R. \& Bowe, B. (2007). Phenomenographic study of students' problem solving approaches in physics. Physics Review Special Topics-Physics Education Research, 3/2, 0201081-02010812.

Wenning, C.J. (2011). The levels of inquiry model of science teaching. Journal Physics Teacher Educations, 6/2, 9-16.

Wieman, C.E., Adam, W. K., Loeblin, P \& Perkins, K. K. (2010). Teaching Physics Sing Simulations Phet Simulations. The Physics Teacher, Vol. 8, 225-227.

Zacharia, C.Z \& Jong, D.T. (2014). One Specific Advantage for Virtual Laboratories That May Support the Acquisition of Conceptual Knowledge is That Reality Can Be Adapted to Serve the Learning Process. Reality Can Be Simplified by Taking Out Details. Cognition and Instruction, Vol. 32. No. 2, 101-158.

Zuckerman, G.A.; Chudinova, E.V. \& Khavkin, E.E. (2009). Inquiry as a pivotal element of knowledge acquisition within the Vygotskian paradigm: building a science curriculum for the elementary. Cognition and Instruction, 16/2, 201-233. 